\title{
CST4 Gene
}

National Cancer Institute

\section{Source}

National Cancer Institute. CST4 Gene. NCI Thesaurus. Code C159791.

This gene plays a role in the inhibition of cysteine proteinases in the saliva, tears, urine and seminal fluid. 